\title{
ASSESSMENT OF SELLERS' MANIPULATIVE BEHAVIOR BY CUSTOMERS AND SELLERS IN THE CONTEXT OF GENERATIONS X, Y AND Z
}

\author{
Róbert Štefko ${ }^{1}$, Miroslav Frankovský ${ }^{2}$, Jana Koval'ová ${ }^{3}$, \\ Zuzana Birknerová ${ }^{4}$, Lucia Zbihlejová ${ }^{5}$ \\ Faculty of Management, University of Prešov in Prešov, Prešov, Slovakia \\ E-mails: ${ }^{1}$ robert.stefko@unipo.sk; ${ }^{2}$ miroslav.frankovsky@unipo.sk; ${ }^{3}$ kovalova.jana@smail.unipo.sk; \\ ${ }^{4}$ zuzana.birknerova@unipo.sk; ${ }^{5}$ lucia.zbihlejova@unipo.sk (corresponding author)
}

Received 28 February 2020; accepted 04 May 2020

\begin{abstract}
In the field of business and trade, we encounter concepts of manipulation and persuasion in the sense of trying to convince someone by applying certain pressure to the mind, opinions, emotions, and behavior, with an aim to cause change. However, literature provides only little information aimed specifically at the manipulative approach of sellers to customers. The purpose of the presented paper is, therefore, to study manipulative behavior of sellers as one of the important determinants of success in business behavior. The research focuses on assessing the manipulative behavior of sellers by customers and by sellers. Data was collected by means of the TBQ-C(r) questionnaire for customers (Trading Behavior Questionnaire - Customers/revision) and TBQ-S(r) for sellers (Trading Behavior Questionnaire - Sellers/revision). Results confirmed the existence of statistically significant differences in the assessment of this behavior from the perspective of customers and sellers, as well as between individual generations. In terms of generations, Generation X customers expressed a higher level of agreement with the recognition of manipulative elements in the behavior of sellers, as opposed to Generation Z, i.e. older customers are more able to recognize the elements of manipulation in the behavior of sellers. In the group of sellers, there was also a significant difference detected between the responses of the Generation $\mathrm{Z}$ and Generation Y respondents. Generation Y sellers expressed a higher level of agreement with the use of manipulative elements of sellers, as opposed to Generation Z, i.e. younger sellers tend to use manipulative elements in their behavior the least. Acquired findings suggest the necessity to approach the issue of sellers' manipulation in a wider context, particularly taking into account the situational and cultural conditions.
\end{abstract}

Keywords: manipulation, behavior, sellers, customers, generations.

JEL Classification: D01, C81.

\section{Introduction}

Manifestations of manipulative behavior are encountered in various areas of everyday life including business and trade. The number of competitors in the business environment is steadily increasing, which is why it is necessary to pay attention to the manipulative behavior of sellers, which may have a negative impact on competitiveness and sustainability (Román, 2003; Chen \& Mau, 2009; Argandoña, 2015). The purpose of this paper is to point out the issue of manipulative behavior of sellers. In the connection with this, the main aim of the presented article is to refer to the different assessment of sellers' manipulative behavior by the sellers and customers in the context of generations $\mathrm{X}, \mathrm{Y}$, and $\mathrm{Z}$.

In a business relationship, customers and sellers are manifested in their own behavioral and response patterns. Koval'ová and Birknerová (2018) talk about buying behavior in connection to customers, and selling behavior in connection to sellers. Business behavior is an interaction that manifests itself externally by their mutual communication between the customer and the seller in the business environment during the sales-purchasing process. If sellers choose the right strategy, then it is possible to built a long-term and useful relationship.

Professional selling behavior, access to work, the personality of the seller, their attitudes and values, the ability to communicate, establish relationships, and choose the right procedures and working methods are the basis of success. However, we are increasingly encountering unethical, manipulative and incorrect attitudes and behavior of sellers (Koval'ová \& Birknerová, 2018). Mansoor (2017) presents the ways to improve the quality of service delivery and customer service through seller approach. An honest and reliable approach is associated with customer loyalty, which can be enhanced 
by credibility, transparency and honesty. As stated by Kimberlee (2018), ethical behavior and an empathetic approach should be a certain "seller code".

The purpose of the presented paper is, thus, to study manipulative behavior of sellers as one of the important determinants of success in business behavior. This behavior is studied only in the "face to face", offline selling. Our research focuses on the assessment of sellers' manipulative behavior by customers and also from the point of view of sellers, especially in the context of the selected generations. For this research we used our own dataset compiled by means of the TBQ-C(r) questionnaire for customers and TBQ-S(r) for sellers.

\section{Manipulative behavior of sellers}

According to Buber (2005), there are two types of relationships in our society: "I and Thou" and "I and It". Modern society is a society of organizations, institutions and depersonalized "I and It" relationships. As reported by Juhás et al. (2010), in this world we are manipulated but we also manipulate others.

More on a scientific level than in everyday life, manipulation is understood in the context of Machiavellian expressions (Christie \& Geis, 1970), which are driven by the desire to control, have power, promote opinions and interests (Prezzolini, 1999). In the context of Machiavellianism, the concept of Machiavellian intelligence (Ruisel, 2003) is also mentioned as the ability to successfully, purposefully manipulate participants in social interaction in order to achieve their own power-motivated goals. Its identification and specification relates to a wider discussion of the existence of several types of intelligence (Sternberg, 1997; Gardner, 1993; Albrecht, 2006; Bar-On 2006). In relation to intelligence in interpersonal relationships, it can be considered an ability to manipulate other people (Goleman, 2006). Negatively assessed manipulation in this specification of the Machiavellian phenomenon is, according to Vernon et al. (2008), possible to include in the Dark Triad, along with narcissism and psychopathy.

According to Delfino (2018), manipulation is a deceptive unfair tactic that people use to achieve their own goals, and Todd (2013) considers it to be a way of influencing behavior with coercion and rational persuasion. Mental manipulation is characterized by Preston (2015) as exerting disproportionate influence through mental distortion and emotional exploitation, with the intention of seiz- ing power, control, benefits and privileges at the expense of the victim.

We talk about manipulation when individuals try to influence others unethically to achieve their goals (Aaron, 2016). Beck (2007) supports this by pointing out that the common denominator of manipulative behavior is unethical behavior of manipulators, which includes e.g. exploitation of people without their own will, disrespect for others, exploitation of credulity, malicious behavior, feign affection. Manipulators work hard and recklessly to achieve their goals (Andrew et al., 2008), their decisions and behavior are coldly rational, without emotions and morality (Juhás et al., 2010), they are deceiving, misrepresenting the statements of others, selfish, ignoring the needs and the wishes of others, and they hate criticism (Tomková \& Birknerová, 2016).

Wróbel (2008) emphasizes influencing and unconsciously fulfilling the manipulator's goals, which are obvious only to him or her. The revelation of manipulative influence is the basis for defense against manipulation. According to Frankovský et al. (2016), it is necessary to draw attention to two intentions of the manipulator: 1) to obtain a specific material benefit, or 2) psychological abuse aimed at dishonoring, which undermines mental integrity and hinders the formation of personal identity and autonomy. Lahnerová (2009) states that it is a manifestation and means of maintaining power, disrupting social relations, restricting the possibility of agreement and cooperation, blocking teamwork and corporate strategies, endangering work performance, and significantly contributing to the deterioration of the overall working atmosphere (Kratz, 2005).

Manipulation is a part of mass communication technology, business, political technology, but also management at all levels. In the field of business and trade, we encounter the concepts of manipulation, manipulative strategies, and persuasion in the sense of trying to convince someone by applying certain pressure to the mind, opinions, emotions, and behavior, with an aim to cause change. It is a targeted intervention in the sphere of thinking of other people (Čmejrková, 2000). Manipulation is a universal social phenomenon, as part of persuasive communication (Machová, 2009), through which the resource seeks to deliberately influence the addressee in order to change his or her mental state in an atmosphere of free choice (Štefko \& Gallo, 2015).

Psychological manipulation, influence, and persuasion often occur in the business as a professional, complex, and unfair treatment, dishonest 
behavior, mind control, and processing of people's consciousness mainly through mass media (Gálik, 2012).

Yarrow (2014) states that once people decide to buy something, it is when they are somehow vulnerable. They're more open-minded in terms of additional purchases, and this gives space to sellers for manipulation with customers.

In the literature we have encountered a lack of information aimed specifically at the manipulative approach of sellers to customers. Therefore, we present the characteristics of manipulative individuals (Brenner, 2016; Caron, 2012) that we have transformed into selling behavior: at the beginning they often praise and use compliments, make aggressive expressions, and have an expressive body language; they offer the only possible solutions for the customer, they do not offer a multiple choice, they offer what makes them the most profit, instead of the best choice for the customer, their own interests and needs are ahead of the customer's needs, feign customer interest, abuse customers because they see potential that can be easily influenced, interfere with personal space of the customer (physically, emotionally, psychologically), and avoid responsibility for their behavior, blaming others.

Linder (2018) states that customer relationships based on manipulation processes, which involve some degree of bias and fraud, only last until the customers realize that they are being treated with contempt rather than with care.

\section{Generation $X, Y$ and $Z$}

Lucero (2017) introduces generation as a group of individuals born at about the same time (usually in the range of about 10-15 years), sharing similar characteristics, preferences and values throughout their lives. These groups often share preferred communication styles, have different shopping and consumer behavior or motivation. Studies have shown that there are three key things that have the greatest impact on generations shaping - parenting, technology and the economy.

Generation is defined by Strauss and Howe (1991) as a large group of people and internally differentiated delineated population. Egan (2014) describes it as a differentiated group of people associated with a period conditioned by a similar way of thinking, decision-making and behavior. Komár (2017) states that at present the term generation is used more in a sociological context than in a biological one. From a sociological point of view, a generation is a group of people born at the same time, formed and connected by specific events, trends and processes. According to Troksa (2016) and Robinson (2017), the main social, political and economic events shape not only the culture but also the ways of perception of each generation. Every generation grew up in a certain period of time, which is connected by a similar way of behavior, thinking and acting (Strauss \& Howe, 1991).

According to Richterová et al. (2015), these generational influences are also reflected in the purchasing behavior, which has been shaped by sharing cultural, political and economic experience, resulting in similar values and worldview. The differences in consumer and purchasing behavior of individual generations have been addressed by several authors (Fromm \& Read, 2018; Kumar, 2014; Bačík et al., 2018). The common denominator of this issue is generational marketing, which uses segmentation of customers into generations.

Years of birth of individual generations have been defined for the purposes of our research, which was carried out in the Slovak conditions (Smolka, 2019; Strauss \& Howe, 1991). The agerelated categorization is as follows:

- Generation X respondents born between years 1965 and 1980,

- Generation Y respondents born between years 1981 and 1995 ,

- Generation $\mathrm{Z}$ respondents born between years 1996 and 2012.

Generation $\mathbf{X}$ spent its youth in a time of relative peace and prosperity (Komár, 2017). According to Frankovský et al. (2019), the Generation X is highly educated, and also Okos (2019) considers it one of the most educated and reliable generations of workers.

Shen Kian et al. (2013) mention independent, technologically skilled and very good multitaskers. Appelbaum et al. (2005) add that they are very rival, enterprising, productive, hardworking, motivated, but less loyal. Kane (2019) points out their flexibility, technological adaptability and their focus on finding solutions. Their motivation is money, status and advancement on the social ranking. According to Okos (2019), they are very good team players; besides hard work they believe in practicality, thorough professionalism, responsiveness, openness to new challenges, and ability to recognize that language skills are a means of success. Their communication is direct, they use straight talk, present facts, like to use email, use informal communication style, share info immediately, and often have the potential to bridge the 
generation gap. They don't like micro-management, use direct conduct, avoid buzz words, and focus on the results (Pencarelli et al., 2018).

They prefer well-established and learned ways and habits as opposed to the subsequent generations. Wroblewski (2018) states that Generation X is a "hybrid" in the area of generational marketing.

Generation $\mathbf{Y}$ is also called "Millennials" or "Net Generation" (Richterová et al., 2015). According to Hershatter, Eprstein (2010), Horváthová and Čopíková (2015), this generation is very smart in searching, classifying, filtering and analyzing information. According to Komár (2017), the representatives of this generation are described as la$\mathrm{zy}$, pointless, narcissistic, and prone to skipping from one job to another. On the other hand, Shen Kian et al. (2013) consider them friendly, positive, interactive, confident, flexible, direct, resourceful, creative, ambitious, patient, entertaining, and teamoriented. They like to learn and overcome challenges but they also require good relationships and a positive working environment. They like sincerity, openness, transparency and time flexibility (Cogin 2012). Horváthová and Čopíková (2015) state that they are highly economically active, require a higher standard of living, prefer a longterm effect, require individual approach in their development and education, like learning new things, are accustomed to saying what they think, and therefore require an environment enabling open communication. Komár (2017) also considers them more open, self-confident, liberal, energetic, talented, creative, and thought-creating. They are characterized by the term "multitasking" and they love to work with their peers. According to Broadbridge et al. (2007), Generation Y is skeptical of the traditional marketing tools, manipulation and tactics. As Prokopets (2017) claims, Generation Y belongs to loyal customers but Jenkins (2017) includes them among the demanding customer group.

A new generation is coming to the fore as the Generation Y representatives are currently in their 20 s and 30s. The Generation $\mathbf{Z}$ group may be on the way to become the best-educated generation yet. Its representatives are approaching adulthood, being open to the current social trends and having a liberal set of attitudes (Parker et al., 2019). Koníčková (2018) claims that Generation $\mathrm{Z}$ is completely different from the previous generations. Since early childhood, its representatives are able to use a variety of digital tools, which subsequently affects them in every area of life. As Rao (2017) states, technologies are a natural part of their lives, which is reflected in patterns of their working and social behavior. For this generation, state-of-the-art technology plays an important role in job decisions, which means that the latest technology is required to attract the best Generation $\mathrm{Z}$ talents (Quan 2019). This generation has the ability to search and control all the necessary information through smartphones, where they can share everything (Csobanka, 2016), which may also apply to business, such as reviews, recommendations or complaints. However, it is necessary to point out the negative development of this generation. As Komár (2017) states, individuals of this generation were born during the crisis period of terrorism, the global crisis and climate change. They live their lives more in the world of the Internet, which negatively shapes their interpersonal relationships and ability to communicate. In the real world, they are unable to manage and solve everyday problems and conflicts sufficiently. In accordance with Štefko et al. (2014), the younger generations tend to seek companies that provide an interactive working environment where they can create their own experience. If organizations implement practices of this kind, then they can capture, use and implement ideas for their products, services, or experience.

Sabaitytė et al. (2019) conducted a research by which they aimed to determine which emarketing communication elements customers prefer during the e-purchase phase, and they used the term "generational cohorts" in their research sample segmentation. As the following research focuses on the offline, "face to face" selling, the attention is paid to the assessment of the use of manipulative behavior by different generations of sellers and the recognition of manipulative behavior of sellers from the perspective of different generations of customers, as defined above.

\section{Research}

For the presented research, in order to assess the manipulative behavior of sellers by customers and by sellers, the data was collected by means of the TBQ-C(r) questionnaire for customers and TBQ$\mathrm{S}(\mathrm{r})$ for sellers. Results confirmed the existence of statistically significant differences in the assessment of this behavior from the perspective of customers and sellers, as well as between the individual generations.

\subsection{Research sample}

The research sample consisted of 348 respondents, $192(55.2 \%)$ of which were customers and 156 $(44.8 \%)$ were sellers, aged between 18 and 52 
years, with an average age of 31.01 years $(\mathrm{SD}=$ 8.669 years). Out of this number, $151(43.4 \%)$ were men and 197 (56.6\%) were women. Generation X (1965-1981) was represented by 83 (23.9\%) respondents, Generation Y (1982-1992) by 151 (43.4\%) respondents, and Generation Z (19932010) was represented by $114(32.8 \%)$ respondents.

\subsection{Research methodology}

The research was aimed at assessing the manipulative behavior of sellers by customers $(n=192)$ and by sellers $(\mathrm{n}=156)$.

The original methodologies by Štefko et al. (2019a) - TBQ-S(r) (Trading Behavior Questionnaire - Sellers) to assess selling behavior by sellers, and by Štefko et al. (2019b) - TBQ-C(r) (Trading Behavior Questionnaire - Customers) to assess selling behavior of sellers by customers were used to collect data.

The methodologies are aimed at assessing selling behavior of sellers in terms of four determinants (committed, assertive, manipulative and distressed behavior). For the purposes of our research, we paid attention to the determinants of manipulative selling behavior in business and trade (i.e.12 items of a 48-item methodology).

This behavior is manifested in the use of manipulative techniques and pressure on customers, feigned interest, empathy, affection and sympathy, incomplete information and lies, disrespect of opinions, abuse of trust. It is about getting out of the comfort zone, forced "yes", and using silence as a leverage. Respondents who score high in the Manipulation factor agree with the claim that pressure and manipulative behavior of sellers have a negative effect on the customers and consequently discourage them from the purchase. Respondents with high scores think customers can recognize, resist, and respond to the manipulative behavior of sellers.

Each of the 12 questionnaire statements contains 6 possible ways of responding to the degree of agreement with this measure $(1=$ definitely no; $2=$ no; $3=$ rather no than yes; $4=$ rather yes than no; $5=$ yes; $6=$ definitely yes). Example: "I perceive manipulative behavior as part of the selling process."

The data were processed by the statistical software IBM SPSS Statistics 22.00.

\subsection{Research results}

In the conducted research we focused on finding the differences in assessing manipulative behavior of sellers by sellers and customers in the context of
Generations $\mathrm{X}, \mathrm{Y}$ and Z. For the purposes of this research, the boundaries of the years for individual generations were set as follows: Generation $\mathrm{X}$ respondents born between years 1965 and 1980, Generation Y respondents born between years 1981 and 1995, Generation Z respondents born between years 1996 and 2012. Data obtained from the respondents were analyzed by the mathematical and statistical method - one-way ANOVA.

The implemented statistical analysis confirmed the existence of statistically significant differences between Generations in assessing the use of manipulative behavior by sellers. At the same time, the analysis confirmed statistically significant differences in assessing the recognition of manipulative behavior of sellers by customers (Tables 1 and 2).

Table 1. Difference between Generations of sellers in using manipulative behavior

\begin{tabular}{|l|c|c|c|c|c|}
\hline & $\begin{array}{c}\text { Sum of } \\
\text { Squares }\end{array}$ & df & $\begin{array}{c}\text { Mean } \\
\text { Square }\end{array}$ & F & Sig. \\
\hline $\begin{array}{l}\text { Between } \\
\text { Groups }\end{array}$ & 5.788 & 2 & 2.894 & 3.201 & .041 \\
\hline $\begin{array}{l}\text { Within } \\
\text { Groups }\end{array}$ & 241.231 & 149 & 1.619 & & \\
\hline Total & 247.019 & 151 & & & \\
\hline
\end{tabular}

Table 2. Difference between Generations of customers in recognizing manipulative behavior of sellers

\begin{tabular}{|l|c|c|c|c|c|}
\hline & $\begin{array}{c}\text { Sum of } \\
\text { Squares }\end{array}$ & df & $\begin{array}{c}\text { Mean } \\
\text { Square }\end{array}$ & F & Sig. \\
\hline $\begin{array}{l}\text { Between } \\
\text { Groups }\end{array}$ & 3.436 & 2 & 1.718 & 2.931 & .048 \\
\hline $\begin{array}{l}\text { Within } \\
\text { Groups }\end{array}$ & 121.813 & 188 & .648 & & \\
\hline Total & 125.249 & 190 & & & \\
\hline
\end{tabular}

In terms of generations, there was a significant difference detected between the responses of the Generation $\mathrm{Z}$ and Generation $\mathrm{X}$ respondents. Customers from Generation X expressed a higher level of agreement with the recognition of manipulative elements among sellers, as opposed to Generation $\mathrm{Z}$, who expressed a lower level of agreement with the recognition of the manipulative behavior of sellers. Older customers are better at recognizing the manipulative elements in the behavior of sellers (Table 3 ). 
Table 3. Comparison of the responses of individual Generations of customers in recognizing the manipulative behavior of sellers

\begin{tabular}{|c|c|c|}
\hline Generation & Mean & Std. Deviation \\
\hline $\mathrm{X}$ & 3.4564 & .70030 \\
\hline $\mathrm{Y}$ & 3.2558 & .82869 \\
\hline $\mathrm{Z}$ & 3.0848 & .83024 \\
\hline Total & 3.2377 & .81191 \\
\hline
\end{tabular}

Table 4. Comparison of the responses of individual Generations of sellers in assessing the use of manipulative behavior of sellers

\begin{tabular}{|c|c|c|}
\hline Generation & Mean & Std. Deviation \\
\hline $\mathrm{X}$ & 3.5091 & 1.30790 \\
\hline $\mathrm{Y}$ & 3.7677 & 1.26190 \\
\hline $\mathrm{Z}$ & 3.3043 & 1.25201 \\
\hline
\end{tabular}

Sellers expressed a higher level of agreement with the use of manipulative elements. In terms of generations, there was a significant difference detected between the responses of the Generation $\mathrm{Z}$ and Generation $\mathrm{Y}$ respondents. Sellers from Generation $Y$ expressed a higher level of agreement with the use of manipulative elements by sellers, as opposed to Generation Z, who expressed a lower level of agreement with the use of manipulative behavior of sellers. Younger sellers use elements of manipulation in their behavior the least (Table 4).

\section{Conclusions}

In the scientific approach to the issue of manipulative behavior in business and trade it is necessary to explain it both in terms of conceptualization, its theoretical definition, and in terms of operationalization, i.e. its quantitative expression.

In terms of conceptualization, it is necessary to distinguish the manipulative behavior from requiring discipline, work performance, etc. Obviously, the definition of this issue as well as its operationalization requires a holistic approach and an interdisciplinary concept of its research.

This complex concept and the multidimensional construct of the problem under consideration are also confirmed by the results of Birknerová et al. (2013), who followed the research of Hunter et al. (1982), who described the components of the structure of manipulation, flattery, deceit, immorality and cynicism. Birknerová et al. (2013) analyzed the gender differences that occurred in assessing the deception factor and in the overall manipulation score. The interpretation of the results was based on role expecta- tions specific to the socio-cultural environment. In a given environment, certain manifestations and manners of manipulative behavior that are typical of women and men are generally expected. According to the authors, these manifestations are more accepted among men than among women.

The research of Frankovský et al. (2016), in which the original methodology for perception of manipulation was used, supports the concept of a holistic approach. The results confirmed the existence of factors of honesty, identification of manipulative behavior, and distrust. The results of their research suggest that individuals who better identify the aspects of manipulative behavior also have a more critical view of information. They perceive it as less objective, true, less enriching knowledge, and less suitable for making the right decision.

As for the limiting factors of the presented research, it is important to accentuate the issue of generalization level of the acquired knowledge and its trans-situationality, i.e. the issue of the situational conditions impact. It is also essential to discuss the acquired findings in the context of cultural and transcultural conditions in terms of how the cultural schemas affect the assessment of the selling behavior. Another limitation to be considered in the future studies on this matter is using the self-report methodologies to carry out research on this particular phenomenon.

\section{Funding}

This research was supported and financed by the scientific grant projects VEGA [1/0807/19: Research on the determinants of trading behavior and marketing effects in the area of neuromarketing and the relation to neuro-linguistic programming] and KEGA [012PU-4/2020: Trading Behavior Creation of the subject and textbook for noneconomic study programs].

\section{Disclosure statement}

Authors declare they have no competing financial, professional, or personal interests from other parties.

\section{References}

Aaron, M. (2016). The surprisong upside of manipulation. https://medium.com/behavior-design/thesurprising-upside-of-manipulation-2af6bb2796b8

Albrecht, K. (2006). Social intelligence. Leadership Excellence, 23(11), 17-18.

Andrew, J., Cooke, M., \& Muncer, S. J. (2008). The relationship between empathy and Machiavellianism: An alternative to empathizing-systemizing 
theory. Personality and Individual Differences, 44(5), 1203-1211.

https://doi.org/10.1016/j.paid.2007.11.014

Appelbaum, S., Serena, M., \& Shapiro, B. (2005). Generation ' $\mathrm{X}$ ' and the Boomers: An Analysis of Realities and Myths. Management Research News, 28(1), 1-33.

https://doi.org/10.1108/01409170510784751

Argandoña, A. (2015). Why is it hard to be ethical in business? Business school. Universtiy of Navarra. https://blog.iese.edu/ethics/2015/07/09/why-is-ithard-to-be-ethical-in-business/

Bačík, R., Fedorko, R., Rigelský, M., Sroka, M., \& Turáková, A. (2018). Perceiving the advertising in gender-generational characteristics. Polish Journal of Management Studies, 1(18), 44-57. https://doi.org/10.17512/pjms.2018.18.1.04

Bar-On, R. (2006). The Bar-On model of EmotionalSocial Intelligence (ESI). Psicothema, 18, 13-25.

Beck, G. (2007). Zakázaná rétorika. Grada Publishing.

Birknerová, Z., Frankovský, M., \& Zbihlejová, L. (2013). Social intelligence in the context of personality traits of teachers. American International Journal of Contemporary Research, 3(7), 11-17.

Brenner, A. (2016). 9 classic traits of manipulative people. Psychology Today.

https://www.psychologytoday.com/us/blog/influx/201610/9-classic-traits-manipulative-people

Buber, M. (2005). Ja a Ty. Kalich.

Caron, N. (2012). Prodej problémovým zákazníkům. Klíč kvyjednávani a prěsvědčováni ( $3^{\text {rd }}$ ed., pp. 130-160). Grada Publishing.

Chen, M. F., \& Mau, L. H. (2009). The impacts of ethical sales behaviour on customer loyalty in the life insurance industry. Services Industrial Journal, 29(1), 59-74. https://doi.org/10.1080/02642060802116339

Christie, R., \& Geis, F. L. (1970). Studies in machiavellianism (1st ed.). Academic Press.

Čmejrková, S. (2000). Reklama v češtině, čeština v reklamé. Leda.

Csobanka, Z. E. (2016). The Z generation. Acta Technologica, 6(2), 63-76.

https://doi.org/10.1515/atd-2016-0012

Delfino, D. (2018). 4 Signs you're being manipulatedand how to stop it. https://www.businessinsider. com/manipulation-signs-2018-5

Egan, J. (2014). Marketing communications (2nd ed.) Sage.

Frankovský, M., Birknerová, Z., \& Koval’ová, J. (2019). Assessment of distressed, proactive and manipulative sellers' behavior in terms of their generation and gender. Balkans Journal of Emerging Trends in Social Sciences, 3(1).

Frankovský, M., Birknerová, Z., \& Mitro, R. (2016). Analýza predikcie vnímania reklamy na základe posudzovania atribútov vnímania manipulácie. Ex- clusive Journal: Economy, Society, Environment, 4(1), 65-73.

Fromm, J., \& Read, A. (2018). Marketing to Gen Z: The rules for reaching this vast and very different generation of influencers. Amacom.

Gálik, S. (2012). Psychologie presvědčováni. Psyché.

Gardner, H. (1993). Multiple intelligences: the theory in practice. Basic Books.

Goleman, D. (2006). Emotional intelligence. Bantam Books.

Horváthová, P., \& Čopíková, A. (2015). Generation Y and its impact on the performance of personnel activities. In T. Kliestik (Ed.), 15th International Scientific Conference on Globalization and its Socio-Economic Consequences (pp. 217-223). University of Zilina.

Hunter, J. E., Boster, F. J., \& Gerbing, D. W. (1982). Machiavellian beliefs and personality: construct invalidity of the machiavellianism dimension. Journal of Personality and Social Psychology, 43(6), 1293-1305. https://doi.org/10.1037/0022-3514.43.6.1293

Juhás, J., Birknerová, Z., \& Litavcová, E. (2010). Otázky manipulácie, mobbingu, sociálnej inteligencie a motivačnej orientácie v učitel'skom prostredi. Sociálni procesy a osobnost (pp. 133-139). PsÚ AV ČR.

Kane, A. (2019). The common characteristics of generation X professionals.

https://www.thebalancecareers.com/commoncharacteristics-of-generation-X-professionals2164682

Kimberlee, L. (2018). Professional and ethical behavior in the workplace. https://smallbusiness.chron.com/professionalethical-behavior-workplace-10026.html

Komár, Z. (2017). Generációelméletek. https://folyoiratok.ofi.hu/ujkozneveles/generacioel meletek

Koníčková, J. (2018). Aká je generácia Z? https://eduworld.sk/cd/jaroslavakonickova/325/aka -je-generacia-z

Koval'ová, J., \& Birknerová, Z. (2018). Determinanty obchodného správania zpohl'adu obchodnikov a zákaznikov. University of Prešov.

Kratz, H. J. (2005). Mobbing - jak ho rozpoznat a jak mu čelit. Management Press.

Kumar, P. (2014). Managing career aspiration of generation Y - a key to business excellence. Global Journal of Multidisciplinary Studies, 3(5), 10-16.

Lahnerová, D. (2009). Asertivita pro manažery. Grada Publishing.

Linder, M. (2018). Don't confuse persuasion and manipulation-your customers won't like it. https://www.business2community.com/consumermarketing/dont-confuse-persuasion-andmanipulation-your-customers-wont-like-it02039031 
Lucero, K. (2017). Generation marketing: how to reach consumers at every age.

https://blog.watermarkadvertising.net/generationmarketing

Machová, S. (2009). Manipulativní komunikační strategie a nepatřičnost. In O. Uličný (Ed.), Eurolingua \& Eurolitteraria (pp. 71-75). TU.

Mansoor, H. (2017). Good seller to great seller: learn to build long-lasting relationship with customers. http://customerthink.com/good-seller-to-greatseller-learn-to-build-long-lasting-relationshipwith-customers/

Okos, A. (2019). X generáció a pénzügyek világában. https://www.oney.hu/blog/x-generacio-apenzugyek-vilagaban

Parker, K., Graf, N., \& Igielnik, R. (2019). Generation Z looks a lot like millennials on key social and political issues. Pew Research Center.

https://www.pewsocialtrends.org/2019/01/17/gener ation-z-looks-a-lot-like-millennials-on-key-socialand-political-issues/

Pencarelli, T., Ali Taha, V., Škerháková, V., Valentiny, T., \& Fedorko, R. (2019). Luxury products and sustainability issues from the perspective of young italian consumers. Sustainability, 12(245), 1-25. https://doi.org/10.3390/su12010245

Preston, N. (2015). 14 Signs of psychological and emotional manipulation. How to spot a manipulator. Psychology Today.

https://www.psychologytoday.com/us/blog/commu nication-success/201510/14-signs-psychologicaland-emotional-manipulation

Prezzolini, G. (1999). Život Niccola Machiavelliho učitele vladařu. Faun.

Richterová, K., Klepochová, D., Kopaničová, J., \& Žák, Š. (2015). Spotrebitel'ské správanie. Sprint dva.

Román, S. (2003). The impact of ethical sales behaviour on customer satisfaction, trust and loyalty to the company: an empirical study in the financial services industry. Journal of Marketing Management, 13(9-10), 915-939. https://doi.org/10.1080/0267257X.2003.9728245

Ruisel, I. (2003). Niektoré aktuálne problémy výskumu inteligencie. Človek a spoločnost', 6(3).

http://www.saske.sk/cas/archiv/3-2003/ruisel-ce.html

Sabaitytè, J., Davidavičienė, V., Straková, J., \& Raudeliūnienè, J. (2019). Decision tree modelling of e-consumers' preferences for internet marketing communication tools during browsing. E a M: Ekonomie a Management, 22(1), 206-221. https://doi.org/10.15240/tul/001/2019-1-014

Shen Kian, T., Yusoff, W. F., \& Rajah, S. (2013). Relationship between motivations and citizenship performance among generation $\mathrm{X}$ and generation $\mathrm{Y}$. International Journal of Academic Research in Business and Social Sciences, 3(11), 53-68. https://doi.org/10.6007/IJARBSS/v3-i11/319
Smolka, S. (2019). Characteristics of Slovak consumers generations. Marketing science \& Inspirations, 1, $2-11$.

Štefko, R., \& Gallo, P. (2015). Using management tools to manage network organizations and network models. In W. Sroka, \& Š. Hittmár (Eds.), Management of network organizations: Theoretical problems and the dilemmas in practice (pp. 249263). Springer. https://doi.org/10.1007/978-3-319-17347-4_17

Štefko, R., Bačík, R., \& Fedorko, R. (2014). The significance of internet marketing tools in terms of building a positive image of an higher education institution. In 24th International Business Information Management Association Conference: Crafting Global Competitive Economies: 2020 Vision Strategic Planning \& Smart Implementation. Conference Proceedings (pp. 1764-1772). Milan: IBIMAC.

Štefko, R., Frankovský, M., Birknerová, Z., Zbihlejová, L., \& Koval'ová, J. (2019a). Possibilities of trading behavior assessment by TBQ -T methodology. In 29th EBES Conference (Vol. 3, pp. 18731883), Lisbon.

Štefko, R., Koval'ová, J., Frankovský, M., \& Birknerová, Z. (2019b). Assessment of possitive proactive behavior of sellers from the perspective of generations of customers Baby boom, $\mathrm{X}, \mathrm{Y}$ and $\mathrm{Z}$ in the context of gender. In Marketing identity 2019: Offline is the new online (pp. 717-736). Smolenice.

Sternberg, R. J. (1997). The concept of intelligence and its role in lifelong learning and success. American Psychologist, 52(10), 1030-1037. https://doi.org/10.1037/0003-066X.52.10.1030

Strauss, W., \& Howe, N. (1991). Generations: The history of America's future, 1584 to 2069. Morrow.

Todd, P. (2013). Manipulation. In The international encyclopedia of ethics (pp. 3139-3145). Blackwell Publishing. Ltd. https://doi.org/10.1002/9781444367072.wbiee585

Tomková, A., \& Birknerová, Z. (2016). Manipulativne techniky vobchodnom správaní - praktikum. Bookman.

Vernon, P. A., Vilani, V. C., Vickers, L. C., \& Harris, J. A. (2008). A behavioral genetic investigation of the Dark Triad and the Big 5. Personality and Individual Differences, 44, 445-452. https://doi.org/10.1016/j.paid.2007.09.007

Wróbel, A. (2008). Výchova a manipulace: podstata manipulace, mechanizmy a proces, vynucování a násilí, propaganda. Grada Publishing.

Wroblewski, M. T. (2018) Generation X consumer behaviour.

https://yourbusiness.azcentral.com/generation-Xconsumer-behaviour-9585.html

Yarrow, K. (2014). Decoding the new consumer mind: how and why we shop and buy (1st ed.). JosseyBas. 